Esta revista forma parte del acervo de la Biblioteca Jurídica Virtual del Instituto de Investigaciones Jurídicas de la UNAM http://www.juridicas.unam.mx 


\section{Sergio E. González Gálvez \\ (1934-2020)}

El embajador emérito Sergio Ernesto González Gálvez nació en Toluca, el 11 de julio de 1934, y falleció en la Ciudad de México, el 27 de marzo de 2020. Licenciado en Derecho por la Universidad Autónoma de Nuevo León (UANL), cursó estudios de posgrado en Derecho Norteamericano y Derecho Internacional en la Universidad de Georgetown. Recibió el Doctorado Honoris Causa por la UANL.

Ingresó al Servicio Exterior Mexicano (SEM) mediante examen de oposición en 1960, alcanzando el rango de embajador en 1975, de embajador eminente en 1987 y de embajador emérito en 1998. Estuvo adscrito a la representación de México ante la Conferencia de Desarme en Ginebra, y en las embajadas de México en Brasil y Japón, país este último en el que fue embajador en dos ocasiones. También se desempeñó como embajador concurrente en la República de Corea y Vietnam. Fue miembro del Comité Jurídico Interamericano de Río de Janeiro.

En la cancillería se desempeñó como director general y director en jefe para Organismos Internacionales, consultor jurídico y subsecretario de Relaciones Exteriores en dos ocasiones. Fue asesor del secretario de la Defensa Nacional y titular de la Unidad de Asuntos Internacionales y Ciudades Hermanas del Ayuntamiento de Toluca.

En la academia, fue profesor en la Universidad Nacional Autónoma de México (UNAM), la Universidad Autónoma del Estado de México, la Universidad Anáhuac, la Escuela Superior de Guerra, el Colegio de Defensa y la Universidad de las Naciones Unidas con sede en Tokio. Fue conferencista en varias instituciones de México y del extranjero y en sesiones externas de la Academia de Derecho Internacional de La Haya.

Es autor de varios textos sobre derecho y política internacional, entre ellos: Controles al uso de ciertas armas convencionales en el derecho internacional; 
La estructura del nuevo derecho internacional; Ignacio L.Vallarta. Reflexiones sobre la soberanía nacional; La Corte Penal Internacional; El uso de armas convencionales en caso de conflicto armado y la injerencia con fines humanitarios: tres temas básicos del derecho internacional humanitario; La reconstrucción de la política exterior de México: principios, ámbitos, acciones, y Diplomacia e interés nacional: una experiencia personal.

Como uno de los mayores expertos en el multilateralismo dentro de la cancillería, González Gálvez participó durante medio siglo en algunos de los más importantes eventos de negociación y codificación del derecho internacional en las organizaciones interestatales, como la OEA y la ONU. A nivel regional, colaboró estrechamente con el embajador García Robles en la negociación del Tratado de Tlatelolco sobre la proscripción de las armas nucleares en América Latina. En la ONU, durante un cuarto de siglo, ocupó la silla de la delegación de México en la Comisión Jurídica de la Asamblea General. Presidió tanto la VII Reunión del Comité Especial de las Naciones Unidas para el estudio de los principios de derecho internacional relativos a las relaciones de amistad y cooperación entre los Estados como el Comité Especial sobre la Definición de la Agresión; actuó, asimismo, como vicepresidente de la Conferencia de expertos gubernamentales sobre la reafirmación y el desarrollo del derecho internacional humanitario aplicable a los conflictos armados. Tuvo una activa participación en la negociación de la Carta de Derechos y Deberes Económicos de los Estados y presidió la delegación mexicana a la Conferencia que aprobó el Tratado de Roma sobre el Estatuto de la Corte Penal Internacional. Actuó como agente de México ante la Corte Internacional de Justicia en la Opinión Consultiva sobre la legalidad de la utilización de las armas nucleares.

En 1973 ocurrió un hecho inusual en los anales de las organizaciones internacionales: presidiendo la Comisión Jurídica de la Asamblea General para la que había sido electo, González Gálvez otorgó la palabra al embajador Jorge Castañeda y Álvarez de la Rosa, quien en su carácter de presidente de la Comisión de Derecho Internacional presentaba su informe.

El embajador González Gálvez solía comentar con sencillez que llegó a la Comisión Jurídica de la Asamblea General cargando el portafolio del embajador Jorge Castañeda, tal y como este último hizo lo propio con el portafolio de Luis Padilla Nervo. 
Esta revista forma parte del acervo de la Biblioteca Jurídica Virtual del Instituto de Investigaciones Jurídicas de la UNAM

El embajador emérito Sergio Ernesto González Gálvez, quien sumó a una sólida formación jurídica su notable habilidad negociadora, fue un diplomático excepcional que sirvió a los mejores intereses de la nación.

José Humberto Castro Villalobos*

* Miembro jubilado del Servicio Exterior Mexicano. 